\title{
PENDIDIKAN AGAMA ISLAM BERBASIS NASIONALISME
}

\author{
Mursidin \\ Institut Agama Islam Sultan Muhammad Syafiuddin Sambas \\ Jl. Raya Sejangkung No. 126 Komplek Perguruan Tinggi Sebayan-Sambas Kalimantan Barat \\ E-mail: mursidinsambas@gmail.com \\ DOI: $10.29313 /$ tjpi.v8i1.4515 \\ Accepted: June 3th, 2018. Approved: October 10th, 2019. Published: October 13th, 2019
}

\begin{abstract}
This article explains about Islamic education based on Nationalism. Islamic education is not only tanght in formal teachings in schools, but also in non-formal education. This fact must be recognized and received attention, because if not then Islamic education is felt to be lame. Therefore, when talking about Islamic education, what is considered is the whole aspects which are also included in it reviewing nationalism. Therefore, it can be concluded that the depletion of national ties due to religion did occur, this is indicated by the emergence of separatist movements in Indonesia. However, this is not because of religious teachings (especially Islam) which do not support nationalism, but because of the followers of the religion experience silence in understanding religious texts. This is where the importance of Islamic education is. That is as a media for inclusive and contextual Islamic understanding. Because until now education is believed to be the most powerful means for the process of transforming values, including the values of nationalism in Islam.
\end{abstract}

Keywords: Islamic Education; Nationalism.

\begin{abstract}
Abstrak
Artikel ini memaparkan tentang pendidikan agama Islam berbasis Nasionalisme. Pendidikan Islam tidak hanya diajarkan dalam ajaran-ajaran formal di sekolah semata, melainkan pendidikan non formal. Kenyataan ini harus diakui dan mendapat perbatian, karena jika tidak maka pendidikan Islam dirasa pincang. Karena itu, ketika berbicara mengenai pendidikan Agama Islam, maka yang dipikirkan adalah keseluruban aspek yang juga tercakup di dalamnya megnkaji tentang nasionalisme. Oleh karena itu dapat disimpulkan bahwa menipisnya ikatan kebangsaan karena agama memang terjadi, hal ini dindikasikan oleh munculnya gerakan-gerakan separatis di Indonesia. Akan tetapi hal itu bukan karena ajaran agama (khususnya Islam) yang tidak. mendukung nasionalisme akan tetapi karena para pemeluk agama mengalami pendangkalan pemahaman teks-teks keagamaan. Disinilah arti penting pendidikan Islam. Yaitu sebagai media transfer pemahaman keIslaman yang inklusif dan kontekstual. Karena sampai sekarang pendidikan dipercaya sebagai sarana paling ampub untuk proses transformasi nilai, termasuk nilai-nilai nasionalisme dalam Agama Islam.
\end{abstract}

Kata Kunci: Pendidikan Agama Islam; Nasionalisme. 


\section{PENDAHULUAN}

Pendidikan merupakan kunci pokok dalam pembentukan jiwa nasionalisme rakyat Indonesia. Oleh karena itu diharapkan melalui pendidikan akan mampu melahirkan generasi yang memiliki kepribadian kuat dan jiwa nasionalisme yang tinggi, dengan begitu akan mampu menciptakan bangsa yang besar dan memiliki keadilan. Lebih spesifik lagi pendidikan Islam dalam konteks kebangsaan sangat diharapkan mampu memberikan pemahaman Islam yang inklusif, komprehensif dan kontekstual. Namun jika pendidikan Islam mengalami kegagalan maka yang terjadi justru sebaliknya. Bangsa Indonesia akan terpecah menjadi serpihan- serpihan kecil dengan batas perbedaan suku, ras, agama atau bahkan hirarki ekonomi. Sehingga tujuan dan cita-cita luhur bangsa yang terangkum dalam Pancasila dan Undang-Undang Dasar 1945 hanya akan menjadi mimpi masa lalu yang tak pantas diceritakan.

Oleh karena itu dapat disimpulkan bahwa menipisnya ikatan kebangsaan karena agama memang terjadi, hal ini dindikasikan oleh munculnya gerakan-gerakan separatis di Indonesia. Akan tetapi hal itu bukan karena ajaran agama (khususnya Islam) yang tidak mendukung nasionalisme akan tetapi karena para pemeluk agama mengalami pendangkalan pemahaman teks-teks keagamaan. Disinilah arti penting pendidikan Islam. Yaitu sebagai media transfer pemahaman keIslaman yang inklusif dan kontekstual. Karena sampai sekarang pendidikan dipercaya sebagai sarana paling ampuh untuk proses transformasi nilai, termasuk nilai-nilai nasionalisme dalam Agama Islam.

\section{PEMBAHASAN}

\section{Nasionalisme}

Nasionalisme berasal dari kata nation yang dipadankan dengan bangsa-bangsa mempunyai dua pengertian, yaitu pengertian antropologis serta sosiologis, dan dalam pengertian politis. Dalam pengertian antropologis dan sosiologis, bangsa adalah suatu masyarakat yang merupakan suatu persekutuan hidup yang berdiri sendiri dan masing-masing anggota persekutuan hidup tersebut merasa satu kesatuan ras, bahasa, agama, sejarah, dan adat istiadat. Sedangkan yang dimaksud bangsa dalam pengertian politik adalah masyarakat dalam suatu daerah yang sama, dan mereka tunduk pada kedaulatan negaranya segabai suatu kekuasaan tertinggi. Badri Yatim, Soekarno, 1999: 67).

Rupert Emerson mendefinisikan nasionalisme sebagai komunitas orang-orang yang merasa bahwa mereka bersatu atas dasar elemen-elemen signifikan yang mendalam dari warisan bersama dan bahwa mereka memiliki takdir bersama menuju masa depan. Sedangkan menurut Ernest Renan, nasionalisme merupakan unsur yang dominan dalam kehidupan sisoal-politik sekelompok manusia dan telah mendorong terbentuknya suatu bangsa guna menyatukan kehendak untuk bersatu. Anggapan ini paralel dengan pandangan Islam sebagaiman termaktub dalam Al- quran surah Al-Hujurat, 49:13.9

Lebih lanjut dikalangan umat Islam dikenal sebuah pepatah yang berbunyi: hubbul wathani minal iman (cinta tanah air adalah bagian dari iman). Ini ditegaskan dalam Alquran yang menghendaki perubahan agar dilakukan oleh masyarakat. QS.13:11: "Sesungguhnya Allah tidak merobah keadaan sesuatu kaum sehingga mereka merobah keadaan yang ada pada diri mereka sendiri.

Orang yang mengendalikan cinta tanah air itu termasuk dari pada iman, adalah hal yang tidak benar. Memang agama Islam tidak bertanah airtetapi kaum Musliminnya yang bertanah air. Agama Islam tidak ada kebangsaan, tetapi kaum Musliminnya berbangsa-bangsa menurut tempat dan daerahnya (Dwi Purwoko dkk, 2001: 37).

\section{Pengertian Pendidikan berwawasan Kebangsaan}

Wawasan adalah kemampuan untuk memahami dan memandang suatu konsep tertentu dan direfleksikan dalam perilaku tertentu sesuai dengan konsep atau pokok pikiran yang terkandung di dalamnya. 
Sedangkan kebangsaan, merupakan tindak tanduk kesadaran dan sikap yang memandang diri sebagai suatu kelompok bangsa yang sama dengan keterikatan sosio kultural yang disepakati bersama. (Benny Nainggolam, http://www.wiziq.com/tutorial/41389-

Wawasan-Kebangsaan- Prajab-III, diakses pada tanggal 08 Januari 2016.

Bangsa yang dimaksud dalam hal ini adalah bangsa Indonesia. Jadi, maksud berwawasan kebangsaan adalah suatu pandangan yang mencerminkan sikap dan kepribadian bangsa Indonesia yang memiliki rasa cinta tanah air, menjunjung tinggi rasa kesatuan dan persatuan, memiliki rasa kebersamaan sebagai bangsa untuk membangun bangsa Indonesia menuju masa depan yang lebih baik, di tengah persaingan dunia globalistik, tanpa harus kehilangan akar budaya yang telah kita miliki.

Hal penting tentang negara adalah hubungan negara dengan agama. Wacana ini mendiskusikan tentang bagaimana posisi agama dalam konteks negara modem (nation state). Hubungan agama dan negara dalam konteks dunia Islam masih menjadi perdebatan yang intensif di kalangan pemikir Muslim hingga kini. Menurut Azyumardi Azra, perdebatan itu telah berlangsung sejak hampir satu abad, dan masih berlangsung hingga dewasa ini. Menurut Azra, ketegangan perdebatan tentang hubungan agama dan negara dalam Islam disulut oleh hubungan yang agak canggung antara Islam sebagai agama dien dan negara daulah berbagai eksperimen telah dilakukan untuk menyelaraskan antara dien dan dawlah dengan konsep dan kultur politik masyarakat Muslim. Seperti halnya percobaan demokrasi di sejumlah negara dunia, penyelarasan dien dan dawlah di banyak negaranegara Muslim yang berkembang secara beragam. Perkembangan wacana demokrasi di kalangan negara-negara Muslim dewasa ini semakin menambah maraknya perdebatan Islam dan negara. (A. Ubaidillah dan Abdul Rozak, 2002: 131)

Perdebatan Islam dan negara berangkat dari pandangan dominan Islam sebagai sebuah sistem kehidupan yang menyeluruh, yang mengatur semua kehidupan manusia, termasuk persoalan politik. Dari pandangan Islam sebagai agama yang komprehensif ini pada dasarnya dalam Islam tidak terdapat konsep pemisahan antara agama dan negara. Dalam hubungan Islam dan negara, Gus Dur menjelaskan bahwa Islam tidak mengenal doktrin tentang negara. Doktrin Islam tentang negara adalah doktrin tentang keadilan dan kemasyarakatan. Dalam pembukaan Undang-Undang Dasar 1945 terdapat doktrin tentang keadilan dan kemakmuran. Tak ada pula doktrin bahwa negara harus berbentuk formalisme negara Islam, demikian pula dalam pelaksanaan hal-hal kenegaraan. (Gus Dur, 1998: 235).

Bagi Gus Dur negara adalah al-Hukm hukum atau aturan. Islam tidak mengenal konsep pemerintahan yang definitif sehingga etik kemasyarakatanlah yang diperlukan. Karenanya menurut Gus Dur Islam tidak perlu diformalkan dalam kehidupan bernegara. Cukup apabila para warga negaranya memperjuangkan sumbangan dan peranan Islam secara informal dalam pengembangan demokrasi. (Abdurrahman Wahid, 2001).

Pemikiran Gus Dur tersebut sejalan dengan Pemikiran Qamaruddin Khan, Dosen Universitas Karachi, yang mengatakan bahwa tujuan al-Qur'an bukanlah menciptakan sebuah negara melainkan sebuah masyarakat, sehingga tidak adanya bentuk negara yang baku dalam Islam membawa hikmah tersendiri. Oleh karena itu, apa pun bentuk serta wujud suatu negara jika di dalamnya terbentuk sebuah masyarakat Qur'ani, maka itu pun sudah merupakan tanda- tanda negara Islam. Asghar (Ali Enginer, 2000: 59). Ketiadaan penjelasan resmi tentang Negara memungkinkan Islam untuk mengikuti kemajuan zaman dan menyesuaikan diri terhadap kondisi dan lingkungan, tempat ia tumbuh dan berkembang.

Adapun pengertian pendidikan berwawasan kebangsaan yang peneliti kutib dari Pendidikan Nasional menjelaskan, dapat ditinjau secara konsepsional dan operasional. Secara konsepsional pendidikan berwawasan kebangsaan mencakup cirri-ciri dan pengertian sebagai berikut: 
Upaya sistematis dan kontinu yang diselenggarakan oleh lembaga pendidikan untuk menyiapkan peserta didik menjadi warga negara yang baik dan bertanggung jawab dalam peranannya pada saat sekarang dan masa yang akan datang.

Upaya pengembangan, peningkatan, dan pemeliharaan pemahaman, sikap dan tingkah laku siswa yang menonjolkan persaudaraan, penghargaan positif, cinta damai, demokrasi dan keterbukaan yang wajar dalam berinteraksi sosial dengan sesama warga Negara Kesatuan Republik Indonesia atau dengan sesama warga dunia.

Keseluruhan upaya pendidikan untuk membentuk peserta didik menjadi warga negara yang baik dan bertanggung jawab melalui upaya bimbingan, pengajaran, pembiasaan, keteladanan, dan latihan sehingga dapat menjalankan peranannya pada saat sekarang dan masa yang akan datang (Departemen Pendidikan Nasional)

Secara operasional, pendidikan berwawasan kebangsaan adalah layanan bimbingan pengajaran atau pelatihan untuk meningkatkan paham, rasa, dan semangat kebangsaan yang baik pada siswa, yang ditunjukkan dengan mengutamakan tingkah laku bersaudara, demokratis, saling menerima dan menghargai, serta saling menolong dalam berinteraksi sosial dengan sesama warga Indonesia.

\section{Tujuan Pendidikan Berwawasan Kebangsaan}

Berbicara mengenai tujuan pendidikan berwawasan kebangsaan terlebih dahulu kita harus menyadari secara seksama, bahwa kita hidup di Negara yang relatif plural dengan berbagai macam kelompok suku, budaya, ras serta Agama dan keyakinan yang harus dimaknai secara positif atas keragaman tersebut. Indonesia sebagai satu negara yang berdasarkan pancasila telah disepakati oleh faunding father.

Pendidikan sebagai alat untuk membungkus ataupun mewadahi cara pandang yang berbeda dalam memahami sebuah persoalan kemasyarakatan harus mampu menjadi tali ikat untuk menumbuhkan semangat persatuan dan rasa kebangsaan, bahwa kita semua adalah saudara sebangsa dan setanah air, jikalau ada satu diantara kita yang disaki atau merasa tersakiti, atau tanah air kita ada yang mencuri demi secuil kepentingan, maka pantang bagi kita untuk membiarkan.

Maka dari itu, pentinglah kita untuk memahami dan mengimplementasikan dari pada tujuan pendidikan yang berwawasan kebangsaan di dalam semua lini jenjang pendidikan baik formal, non-formal, maupun in-formal. Tujuan dari pendidikan berwawasan kebangsaan meliputi, antara lain sebagai berikut: Meningkatkan pengertian, pemahaman, dan persepsi yang tepat tentang persatuan dan kesatuan antar sesama warga NKRI.

Menanamkan jiwa kepemimpinan dan tanggung jawab sebagai penerus Bangsa Indonesia.

Mengembangkan kepekaan sosial, solidaritas, toleransi, dan saling mengenal serta saling menolong antar sesama warga NKRI walaupun berbeda latar belakang.

Meningkatkan kemampuan dan keterampilan siswa dalam mengelola konflik antar-pribadi dan antar kelompok.56

Adapun tujuan dari pendidikan berwawasan kebangsaan tidak berbeda dari visi dan misi pendidikan nasional, yaitu menjadikan peserta didik secara aktif untuk mengmbangkan potensi dirinya, memiliki kekuatan spiritual keagamaan, pengendalian diri, kepribadian, kecerdasan, akhlak mulia, serta keterampilan yang diperlukan dirinya, masyarakat, bangsa dan Negara. (Undang-undang Sistem Pendidikan Nasional, 2009: 3 )

Pendidikan berwawasan kebangsaan berorientasi terhadap; 1) Paham kebangsaan, 2) Rasa kebangsaan, 3) Semangat kebangsaaan. Paham kebangsaan merupakan refleksi dari kesadaran individu akan kebhinneka tunggal ikaan masyarakat Indonesia. Refleksi kesadaran tersebut dijadikan pedoman berperilaku dalam kehidupan berbangsa dan bermasyarakat yang majemuk.

Jadi, Pendidikan Islam berwawasan kebangsaan adalah, suatu cara pandang sistem pendidikan Islam yang mempunyai nilai-nilai, 
Visi sosial kemasyarakatan yang dilandaskan pada ajaran Islam sebagai sarana integrasi bangsa, berarti rasa kesatuan yang tumbuh dalam hati sekelompok manusia berdasarkan cita-cita yang sama dalam satu ikatan organisasi kenegaraan Indonesia. Persatuan Indonesia adalah proses untuk menuju terwujudnya nasionalisme Indonesia.

\section{Materi Pendidikan Berwawasan Kebangsaan}

Pendidikan adalah bagian dari pembangunan bangsa, tentunya harus menekankan pada upaya untuk mencerdaskan kehidupan dan semangat kebangsaan, sehingga menjadi manusia Indonesia yang memiliki kepribadian utuh. Salah satu ciri manusia yang utuh adalah bermutu, manusia yang memiliki tanggung jawab atas keilmuannya dan tanggung jawab atas kebangsaannya dengan sendirinya memiliki wawasan kebangsaan.

Berkaitan dengan materi pendidikan berwawasan kebangsaan, perlu melihat realitas pendidikan di Indonesia hari ini. Fenomena yang ada bahwa, beberapa kelompok yang merongrong ataupun menggerogoti semangat kebangsaan justru beberapa dari output lembaga pendidikan kita. Maka dirasa perlu materi pendidikan berwawasan kebangsaan yang diintegrasikan dalam materi pelajaran diberbagai jenjang pendidikan, baik formal maupun non-formal. Adapun materinya sebagai berikut:

\section{Cinta Tanah Air}

Setiap peserta didik harus mencintai tanah air sebagai ruang hidup dalam menjalankan kehidupannya yang selalu mendapat ancaman baik dari dalam maupun luar negeri, antara lain: diwujudkan menjaga lingkungan hidup, mengenal wilayah tanah air, dan mencintai produk dalam negeri agar tumbuh rasa nasionalisme. Sehingga, kesadaran bertanah air satu, tanah air Indonesia menjadi semangat bersama bagi semua peserta didik.

\section{Kesadaran Berbangsa dan Bernegara}

Peserta didik harus dituntut untuk mempunyai kesadaran atas tanggung jawabnya sebagai masyarakat yang didukung pengetahuan, keterampilan, kompetensi serta pribadi manusia yang beriman, sehat, cakap, kreatif, mandiri, dan bersikap demokratis, antara lain diwujudkan dengan bersikap disiplin, bertanggung jawab, saling menghargai dan menghormati, menjaga kerukunan, berjiwa gotong royong, mendahulukan kewajiban dari pada hak sebagai warga negara, serta mendahulukan kepentingan negara dan bangsa dari pada kepentingan pribadi dan kelompok. Sehingga peserta didik mampu menyadari atas kemajemukan yang ada dalam bangsa ini dan melekat dalam jiwa-jiwa sanubari, baik suku, ras, agama dan budaya sebagai bagian dari pada kehidupan berbangsa dan bernegara.

\section{Pancasila Sebagai Ideologi Negara}

Pancasila adalah dasar ideologi negara yang sah, dan tidak ada ideologi lain. Ketentuan ini adalah hal yang mutlak dan telah disepakati oleh founding father republik ini. Nilai-nilai ajaran yang ada pada pancasila harus dimasukkan dalam lini materi pelajaran. Sehingga mampu mewujudkan tatanan peserta didik yang mengacu dan berlandaskan ideologi Pancasila, antara lain diwujudkan dengan bertaqwa kepada Tuhan YME, menjalankan kewajiban agama, mempunyai kesadaran membantu sesama, memelihara persatuan dan kesatuan, mengedepankan musyawarah untuk mufakat, serta mewujudkan keadilan sosial.58

Dengan materi seperti ini, semua peserta didik diberbagai jenjang pendidikan termasuk para pendidik mempunyai hak dan kewajiban melaksanakan semangat kebangsaan dan Bela Negara dalam semua aspek kehidupan. Pendidikan berwawasan kebangsaan harus berupaya membuat peserta didik menjadi senang dan riang gembira, tanpa melupakan disiplin dan tanggung jawab. Disamping itu, menggunakan bahasa-bahasa yang sederhana dan mudah dimengerti, sehingga tidak terkesan "wajib militer" dan/atau "militerisasi sipil", sehingga menakutkan. Gunakan diskusi dan praktek lapangan yang sederhana untuk mudah meresapi dan menghayati dalam pendidikan kebangsaan. 


\section{Metode Pendidikan Berwawasan Kebangsaan}

Pendidikan berwawasan kebangsaan menjadi sangat penting untuk diketahui dan dipelajari oleh peserta didik baik dalam lembaga pendidikan formal maupun non formal, dan segala jenjang pendidikan, karena selama ini pendidikan hanya mengajarkan kepada peserta didik dalam satu sudut pandang keilmuan, tanpa menyinggung hal-hal yang mengenai kebangsaan, yang akhimya wawasan kebangsaan sangat minim sekali untuk dimiliki oleh peserta didik, padahal adanya pendidikan ini tidak luput untuk menjadikan peserta didik sebagai penerus estafet perjuangan pemimpin bangsa, sebagaimana dalam tujuan pendidikan yakni untuk menjadi khalifah atau wakil Tuhan di bumi.

secara jelas disebutkan, bahwa tujuan Pendidikan Nasional, yaitu mencerdaskan kehidupan bangsa dan mengembangkan manusia Indonesia seutuhnya, yaitu manusia yang beriman dan bertakwa terhadap Tuhan Yang Maha Esa dan berbudi pekerti luhur, memiliki pengetahuan dan ketrampilan, kesehatan jasmani dan rohani, kepribadian yang mantap dan mandiri serta rasa tanggung jawab kemasyarakatan dan kebangsaan. (Hasbullah, 2005: 45).

Untuk itu perlu adanya metode maupun pola dalam pembelajaran pendidikan kebangsaan di berbagai jenjang pendidikan.

\section{Metode Integrasi}

Integrasi dalam kegiatan pembelajaran

berarti memadukan, memasukkan, dan menerapkan nilai-nilai yang diyakini baik dan benar dalam rangka membentuk, mengembangkan, dan membina tabiat atau kepribadian peserta didik sesuai jati diri bangsa tatkala kegiatan pembelajaran berlangsung. (Anik Ghufron, 2010: 17). Karena memang pendidikan berwawasan kebangsaan tidak merupakan mata pelajaran yang berdiri sendiri, oleh karenanya wawasan kebangsaan diintegrasikan dalam kurikulum dan berfungsi menjadi penguat kurikulum yang sudah ada.
Ada beberapa cara untuk mengintegrasikan nilai- nilai pendidikan kebangsaan dalam mata pelajaran, antara lain: mengungkapkan nilai-nilai yang terkandung dalam mata pelajaran, pengintegrasian nilai-nilai kebangsaan secara langsung ke dalam mata pelajaran, menggunakan cerita untuk memunculkan nilai-nilai, menceritakan kisah hidup orang besar, sejarah bangsa dan para pemimpinnya, kemudian lewat cara merefleksikan berbagai permasalahan yang melanda di bangsa ini, menggunakan lagu-lagu atau musik-musik kebangsaan, untuk merangsang jiwa siswa, dan menggunakan berbagai kegiatan seperti kegiatan amal, kunjungan sosial, dan kelompok-kelompok kegiatan untuk memunculkan nilai-nilai kemanusiaan dan semangat kebangsaan. Dan akhirnya semua itu bisa melekat dalam diri siswa, yang tidak hanya pemahaman keilmuan, namun juga faham kebangsaan. (Zubaedi, 2011: 273). Untuk mengintegrasikan pendidikan kebangsaan ke dalam semua mata pelajaran membutuhkan kerjasama sinergiskolaboratif antara mata pelajaran dan pendidikan kebangsaan peserta didik. Sistem pendidikan harus juga mengintegrasikan nilainilai kebangsaan dalam kurikulum pembelajaran. Oleh karena itu, integrasi nilainilai yang terkandung dalam karakter bangsa harus dimasukkan ke dalam kegiatan pembelajaran pada setiap mata pelajaran untuk membentuk karakter bangsa, melalui kajian, aplikasi, dan kegiatan lainnya yang mempunyai nilai-nilai pendidikan kebangsaan.

\section{Metode Problem Solving}

Metode pemecahan masalah (problem solving) adalah penggunaan metode dalam kegiatan pembelajaran dengan jalan melatih siswa menghadapi berbagai masalah baik itu masalah pribadi atau perorangan maupun masalah kelompok untuk dipecahkan sendiri atau secara bersama-sama.

Penyelesaian masalah merupakan proses dari menerima tantangan dan usaha usaha untuk menyelesaikannya sampai menemukan penyelesaiannya. menurut Syaiful Bahri Djamara bahwa: Metode problem solving 
(metode pemecahan masalah) bukan hanya sekedar metode mengajar tetapi juga merupakan suatu metode berfikir, sebab dalam problem solving dapat menggunakan metode lain yang dimulai dari mencari data sampai kepada menarik kesimpulan. (Syaiful Bahri Djamara dan Aswan Zain, 2006: 103).

Menurut Sudirman metode problem solving adalah cara penyajian bahan pelajaran dengan menjadikan masalah sebagai titik tolak pembahasan untuk dianalisis dan disintesis dalam usaha untuk mencari pemecahan atau jawabannya oleh siswa. (Sudirman, dkk. 1987: 146).

Dengan metode ini pembelajaran bisa dikaitkan dengan masalah-masalah kebangsaan untuk dikaji dan dianalisa dengan proses kehidupan sehari-hari, upaya untuk meningkatkan pola berfikir peserta didik dalam memecahkan sebuah permasalahan, misalkan isu-isu sosial kemasyarakatan yang nampak dalam kehidupan berbangsa dan bernegara.

\section{Agama Islam Memandang Nasionalisme Indonesia}

Islam sebagai agama terakhir yang menyempurnakan ajaran-ajaran terdahulu tentunya memiliki kelebihan, yaitu mampu menjawab semua permasalahan umat dalam berbagai segi dan rentang waktu. Begitu juga dalam menghadapi permasalahan kebangsaan. Agama Islam sangat mendukung berbagai upaya untuk kesejahteraan dan kemaslahatan umat manusia.

Islam pada awalnya memiliki citra dan cerita yang positif karena penyebarannya dengan jalan damai dan berperan dalam peningkatan peradaban manusia. "Bahkan secara politis Islam telah menjadi kekuatan dominan yang mampu menyangga dan mempersatukan penduduk nusantara yang bertebaran ini ke dalam sebuah identitas baru yang bernama Indonesia, sekalipun pada akhirnya secara legal formal ikatan keindonesiaan ini diatur dan diperkuat oleh administrasi dan ideologi negara."'11 Zainuddin Maliki, 2000: xxv).
Dalam lingkup sejarah Indonesia agama Islam telah menunjukkan arti pentingnya dalam pembentukan kebangsaan Indonesia. Sejarah telah mencatat bahwa pondok pesantren dengan para kyainya menjadi basis paling kuat untuk melawan penjajah. Sebagaimana telah ditunjukkan dalam sebuah resolusi jihad yang dikeluarkan NU pada tanggal 22 Oktober 1945. Pesan jihadnya mampu mengobarkan semangat nasionalisme melawan penjajah seperti yang dimiliki oleh penyiar radio, Bung Tomo.

Sebelum membahas terlalu jauh, disini akan dipetakan beberapa gagasan tokoh Muslim dari berbagai aliran pemikiran tentang kaitan antara agama dan negara. Dalam konteks keindonesiaan terdapat banyak paradigma yang menjelaskan konsep hubungan antara agama dan Negara-Bangsa Indonesia. Hal ini setidaknya bisa dipetakan dalam tiga golongan dengan paradigma masing- masing, yaitu golongan dengan paradigma integral, paradigma sekular dan paradigma simbiotik.

Paradigma Integral. Paradigma ini memiliki konsep tentang bersatunya agama dan negara. Dengan arti lain negara merupakan lembaga politik sekaligus lembaga keagamaan. Paham ini dianut oleh madzab Syiah dan banyak tokoh fundametalis. Kartosoewirjo, Amin Rais dan Hidayat Nur Wachid merupakan beberapa di antara tokoh Indonesia yang memiliki pemahaman sebagaimana paradigma ini.

Pemikiran politik para penganut aliran ini cenderung ke arah Islam formal yang menghendaki negara-agama (teocratic state). Negara Pancasila yang selama ini terbangun dinilai belum final dan harus disempurnakan dengan menggunakan Islam sebagai tandingan konsep nation-state. (Ali Maschan Moesa, 2006: 285). Dengan begitu cita-cita yang diinginkan adalah negaraIndonesia dengan asas atau berundang- undang dasar Islam.

Paradigma Sekular atau idealis radikal. Paradigma ini mengangap bahwa antara agama dan negara merupaka suatu yang terpisah. Oleh karena itu, para penganut paham ini menolak Agama Islam dijadikan sebagai dasar negara. Paham ini dianut oleh Soekarno. 
Agama yang idealnya sangat membela hak-hak dan kebesaran Tuhan dan menekankan kewaijban manusia namun dianggap sangat sedikit menghargai keunggulan potensi manusia, menjadi alasan para penganut aliran ini. Menururt Komarudin Hidayat hal ini disebabkan trauma akan agama yang dinilai cenderung eksklusif, tidak ilmiah, dan mendorong orang menjadi fanatik terhadap kelompoknya, tidak toleran terhadap kelompok yang berbeda dan bahkan cenderung otoriter. (Zainuddin Maliki, 2000: xxii). Oleh karena itu, agama dimasukkan dalam ruang privasi dan tidak dikehendaki ikut campur dalam konteks yang lebih luas seperti dalam lingkup politik kenegaraan.

Paradigma Simbiotik atau akomodatif. Paradigma terakhir ini memiliki konsep bahwa antara agama dan negara memiliki hubungan timbal balik yang saling membutuhkan dan saling mendukung. Cak Nur dan Gus Dur adalah di antara tokoh Muslim Indonesia yang menganut pendapat ini.

Pemikiran politik aliran ini umumnya cenderung ke arah Islam substansial. Mereka menganggap dengan ideologisasi Islam berarti telah mereduksi Islam. Islam ditempatkan sebagai komplementer konsep nation-state dan Negara Pancasila dianggap telah final. (Ali Maschan Moesa, 2006: 285).

Relasi ketiga ini sebenarnya juga memiliki masalah. Yaitu ketika Agama Islam yang lebih mengedepankan universalitas sedangkan negara selalu berbicara mengenai batasan dan lokalitas tertentu. "Dalam merespon persoalan ini, para kiai berpendapat bahwa Islam seharusnya cukup diposisikan sebagai dasar moralitas dalam mengatur negara." (Ali Maschan Moesa, 2006: 285).

Dari tiga tipe tersebut, Indonesia selama ini lebih menginginkan model terakhir, yaitu agama diharapkan mampu mensuport kehidupan kebangsaan. Hal ini melihat konteks Indonesia yang besar dan terdiri dari berbagai suku, agama, dan budaya. Keanekaragaman itu jika tidak diakomodir secara baik akan berpotensi menimbulkan masalah yang justru menghancurkan bangsa sendiri.

\section{Pendidikan Agama Islam Berbasis Nasionalisme}

Islam merupakan penuntun dan sumber nilai bagi para Muslim. Adapunproses transformasi ajaran Islam itu bisa dilakukan melalui berbagai jenis pendidikan. Dengan begitu Pendidikan agama Islam memiliki tugas yang berat. Akan tetapi selama ini pedidikan di Indonesia dinilai gagal dalam mengemban tugasnya. Begitu juga yang terjadi pada pendidikan agama yang seharusnya mengambil peran sentral dalam membangun karakter masyarakat dalam kehidupan nyata.

Menurut Muhaimin kegagalan tersebut setidaknya disebabkan oleh dua aspek. Pertama pendidikan agama telah kehilangan ruh moralnya karena masih berpusat dengan persoalan yang bersifat simbolik, ritualistik dan legal formal. Kedua, kegiatan pendidikan agama yang tidak mampu menyentuh ranah psikomotorik sehingga apa yang telah diajarkan kepada peserta didik tidak mampu diwujudkan dalam tingkah nyata dalam kehidupan. (Qodri Azizy, 2002: 82-85)

Di lain pihak Qodri Azizy menilai nilainilai ideal agama Islam yang tidak terwujud di kehidupan sehari-hari dalam sistem sosial adalah bukti adanya krisis multi dimensi atau krisis lingkaran setan, dan untuk memperbaikinya harus dengan kembali kepada ajaran agama. Perbaikan ini harus dimulai dari para pemimpin bangsa dan elit politik dalam beretika sosial, sedangkan untuk jangka ke depan bangsa ini harus diperbaiki melalui pendidikan, termasuk pendidikan agama.

Pelajaran agama dan praktek etika sosial harus mendapat perhatian serius di setiap sekolah/madrasah, sejak dari kebijakan dan kurikulum, sampai dengan praktek dan evaluasinya agar pendidikan agama mencapai tujuan sejatinya, yaitu terbangunnya kehidupan masyarakat yang bermoral secara ideal dan prakteknya atau dengan kata lain terwujudnya realitas masyarakat dengan perilaku moralitas. (Qodri Azizy, 2002: 85).

Sedangkan Dedi Supriadi menyatakan, penjabaran tujuan pendidikan yang salah satunya adalah dalam pencapaian iman dan taqwa (imtaq) mengalami kesulitan. Ia menilai 
dalam praktiknya pendidikan lebih mengutamakan dimensi tujuan yang bersifat instrumental yang berkenaan dengan aspek pengetahuan dan keterampilan. Hal ini karena sistem persekolahan lebih benyak mengejar pembelajaran akademik bidang pengetahuan dan keterampilan tertentu. Alasan lain adalah karenapengembangan kedua pelajaran tersebut lebih mudah diamati dan diukur perkembangannya. (Dedi Supriadi, 2004: 122).

Dengan begitu bisa disimpulkan bahwa pendidikan Agama Islam mengalami berbagai kendala dalam mencapai tujuan. Salah satu bukti kegagalannya adalah ketidakmampuannya dalam menanamkan ajaran-ajaran agama kepada masyarakat untuk bisa dipraktikkan dalam kehidupan nyata.

Sebagai contoh meski Agama Islam sangat mencintai perdamaian akan tetapi banyak penganutnya yang justru melakukan tindakan teror, agama menghendaki keadilan sosial akan tetapi masyarakat enggan membayar zakat dan pajak, atau banyaknya kasus korupsi dan politik yang kotor di Indonesia.

Tantangan pendidikan agama Islam saat ini adalah bagaimana pendidikan tersebut tidak hanya mengajarkan pengetahuan tentang agama, akan tetapi dapat mengarahkan peserta didik memiliki kualitas keberagamaan yang kuat sehingga pendidikan agama mampu membentuk sikap dan kepribadian masyarakat yang memiliki iman dan taqwa yang sesungguhnya, dan juga dipraktekkan dalam dunia realitas secara kontekstual.

Adapun kendala yang dihadapi oleh pendidikan Agama Islam adalah pengajarannya yang tidak menyentuh aspek efektif dan psikomotor. Hal ini karena pengajarannya yang tidak lebih dari sekedar formalitas, ritualitas dan sekedar pengetahuan. Padahal pada intinya pendidikan agama lebih jauh dari itu, yaitu berkenaan dengan pembangunan moral dan menyentuh ranah afektif dan psikomotorik.

Seharusnya para guru mengacu pada peraturan yang telah dibuat pemerintah mengenai penilaian hasil belajar agama yaitu melalui pengamatan terhadap perubahan perilaku dan sikap untuk menilai perkembangan afeksi dan kepribadian peserta didik; serta ujian, ulangan, dan/atau penugasan untuk mengukur aspek kognitif peserta didik. (PP Nomor 19 tahun 2005).

Pendidikan Islam tidak hanya diajarkan dalam ajaran-ajaran formal di sekolah, akan tetapi lebih banyak komunikasi dari luar sekolah. Harus diakui pendidikan memiliki begitu banyak model pengajaran, baik yang berupa pendidikan sekolah atau non formal seperti perkumpulan arisan dan pengajian. Kenyataan ini harus diakui dan mendapat perhatian, karena jika tidak maka pendidikan Islam dirasa pincang. Karena itu, ketika berbicara mengenai perbaikan pendidikan Agama Islam, maka yang dipikirkan adalah keseluruhan aspek yang juga tercakup di dalamnya pendidikan formal, non formal dan informal.

Menghadapi dunia yang semakin modern, pendidikan Islam harus mampu menyesuaikan diri. Dua hal yang saling terkait dalam pendidikan Islam saat ini adalah pembaharuan (tajdid) dan modernisai (alhadasah). Abdurrahman Wahid, 2006: 225). Dalam pembaharuan pendidikan Islam ajaranajaran formal harus lebih diutamakan, dan kaum Muslimin harus dididik dengan ajaran-ajaran agama mereka. Adapun yang diubah adalah cara-cara penyampaiannya sehingga ia akan mampu mampu memahami dan mempertahankan kebenaran. Adapun modernisasi pendidikan Islam menuntut umat Islam untuk menjawab tantangan modernisasi. Tantangan seperti pengentasan kemiskinan, lingkungan hidup dan kebangsaan. Islam memiliki kepedulian yang tinggi terhadap keadaan dan masalah yang dihadapi sebuah bangsa atau negara. Dalam negara Indonesia yang plural ini, KH Ahmad Siddiq mengajukan konsep persaudaraan yang terdiri dari empat hal. Pertama, persaudaraan sesama manusia (ukhuwah Basyariyah), yaitu cara bergaul sesama umat manusia tanpa ada faktor pembeda, kedua,persaudaraan sesama umat beragama (ukhuwah diniyah), sebagai landasan sikap saling menghormati sesama umat beragama, ketiga, persaudaraan sesama umat Islam (ukhuwah Islamiyah), prinsip persaudaraan internal tanpa melihat 
organisasinya dan keempat, persaudaraan sesama warga negara (ukhuwah wathoniyah), prinsip persaudaraan dalam rangka menjaga persatuan dan kesatuan dan mempertahankan kedaulatan negara dari ancaman apapun.

Empat prinsip inilah yang seharusnya ditanamkan dalam pribadi masyarakat Indonesia. Umat Islam tidak boleh melupakan sebuah kenyataan penting berupa rumusan ajaran Islam yang sebenarnya, sebagaimana yang ada pada ayat Al Quran bahwa Allah telah menciptakan manusia dengan segala perbedaannya untuk saling mengenal dan sikap dasar dari ketentuan Tuhan tetap berpegang kepada tali Allah secara keseluruhan, dan jangan terpecah-belah.

Sikap dasar ini juga merupakan antisipasi terhadap kenyataan akan masa depan agama Islam dan kaum Muslimin, seperti telah terbukti dewasa ini yaitu Islam merupakan agama besar, tanpa mengecilkan agama-agama lain. Inilah yang belum disadari oleh sebagian Muslim sehingga mereka memilih jalur yang kaku dan berhalauan keras. Sikap-sikap keras yang kita lihat masih ada di kalangan kaum Muslimin mudah-mudahan akan hilang melalui pendidikan yang lebih baik dan komunikasi yang lebih intens.

Proses sosialisasi hasil internalisasi yang telah didinamisir, dapat dikembangkan pula dengan mendayagunakan forum-forum keagamaan (seperti pengajian, musyawarah hukum agama, pendidikan agama dan sebagainya) begi keperluan membicarakan halhal yang perlu diinternalisasikan secara dinamis, seperti dalam hal penggunaan semua forum di atas untuk meningkatkan kesadaran akan perlunya orientasi baru bagi pembangunan, dan seterusnya.

\section{KESIMPULAN}

Nasionalisme dapat dikatakan sebagai sebuah situasi kejiwaan di mana kesetian seseorang secara total diabadiakan langsung kepada negara, di mana masyarakatnya dipersatukan karena ras, bahasa, agama, sejarah dan adat. Hal tersebut berdasar pada penciptaan manusia yang terdiri atas laki-laki dan perempuan, bersuku-suku dan berbangsabangsa.

Nasionalisme merupakan semangat kelompok manusia yang hendak membangun suatu bangsa yang mandiri, dilandasi satu jiwa dan kesetiakawanan yang besar.

Mencintai tanah air tidak dilarang agama. Yang dilarang adalah mengurus suatu negara atau mengajak orang lain untuk mengurusnya dengan asa kebangsaan tanpa mengambil atura Islam. Semangat nasionalisme serta cinta tanah air dan menyatukannya dengan aturan Islam adalah sikap terpuji. Sebagaimana Alquran surah Al-Hujurat mengakui eksistensi bangsa-bangsa, tapi menolak nasionalisme sempit yang mengarah kepada Ashabiyah. Kebangsaan adalah suatu fitrah dan alamiyah.

Semua hal ini hanya bisa tercapai lewat pendidikan. Pendidikan yang tidak bertujuan membuat seseorang menjadi pintar saja atau sekarang menjadi kaya raya, tapi pendidikan seutuhnya yang mampu menjadi seorang manusia menjadi manusia seutuhnya, terbebaskan dari sifat-sifat hewani dalam dirinya.

Adapun yang bisa dilakukan adalah sebagai berikut: a) Mengembangkan materi agama yang komprehensif sehingga materi ini dapat menampilkan wajah agama sebagai karunia bagi pemeluk agama tersebut maupun pemeluk agama lain (rahmatan lil alamin) di dalam semua bidang kehidupan. b) Mengembangkan metode pengajaran agama yang kritis, dialogis, dan aplikatif dengan tetap berpegang pada standar kaidah-kaidah agama. c) Menciptakan kehidupan keagamaan (intra dan antar umat beragama) yang interaktif, dialogis dan toleran sehingga menumbuhkan semangat kebersamaan dan kerjasama.

\section{DAFTAR PUSTAKA}

Abdulah, Abdurrahman Saleh. (1982). Educational Theory; a Quranic Outlook. Makkah: Umm al-Qura University. Djamara, Syaiful Bahri, Aswan Zain. (2006). Strategi Belajar Mengajar. Jakarta: Rineka Cipta. 
Enginer, Asghar Ali. (2009). Devolusi Negara Islam, terj. Imam Muttaqin. Yogyakarta: Pustaka Pelajar.

Ghufron, Anik. (2010). Integrasi Nilai-Nilai Karakter Bangsa pada Kegiatan Pembelajaran, Yogyakarta: UNY. Edisi Khusus Dies Natalis UNY.

Gus Dur. (1998). Politik Sebagai Moral, Bukan Institusi dalam Tabayun Gus Dur. Yogyakarta: LKiS.

Hasbullah. (2005). Dasar Ilmu Pendidikan. Jakarta: PT Raja Grasindo Persada.

Maliki, Zainuddin. (2000). Agama Rakyat Agama Penguasa. Yogyakarta: Galang Press.

Moesa, Ali Maschan. (2007). Nasionalisme Kyai. Yogyakarta: Lkis.

Muhaimin. (2003). Arah Baru Pengembangan Pendidikan Islam. Bandung: Nuansa Cendekia.

Nainggolam, Benny. (2016). Berwawasan Kebangsaan dalam Kerangka NKRI, lihat:

http://www.wiziq.com/tutorial/41 389-Wawasan-Kebangsaan- PrajabIII, diakses pada tanggal 08 Januari 2016.

Natsir, Hasyim Asyari. (2001). Depok: Permata Artika Kreasi.

Sudirman, dkk. (1987). Ilmu Pendidikan. Bandung: Remadja Karya.

Supriadi, Dedi. (2004). Membangun Bangsa Melalui Pendidikan, Bandung: Remaja Rosda Karya.

Ubaidillah, A. Rozak, Abdul. (2012). Pancasila, Demokrasi, HAM, dan Masyarakat Madani. Jakarta: Kencana Prenada Media Group.

Undang-undang Sistem Pendidikan Nasional. (2009) Cet. III Yogyakarta: Pustaka Pelajar.

Wahid, Abdurrahman. (2001). Nasionalisme, Tasawnuf, dan Demokratisasi. dalam Kompas tanggal 2 April 2001. . (2006). Islamku Islam Anda Islam Kita, Jakarta: The Wahid Institute.
Yatim, Badri, Soekarno. (1999). Islam dan Nasionalisme. Jakarta: Logos Wacana Ilmu.

Zubaedi. (2011). Desain Pendidikan Karakter, Konsepsi dan Aplikasinya dalam Lembaga Pendidikan. Jakarta: Kencana Prenada Media Group. 